\title{
HOSTEL CATEGORIZATION AS AN ASPECT OF IMPROVING MARKET POWER OF DOMESTIC ACCOMMODATION
} FACILITIES

\author{
Jovan Vukotić \\ HMC - Hotel Management Company, \\ Belgrade, Serbia
}

\begin{abstract}
:
Hostels as well as restaurants with the specific hotel organization characteristics, spatial distribution, as well as technological and other requirements in the provision of accommodation services, with its unique offer of accommodation facilities, have provided their own importance and positioning worldwide. Their recognition and demand in the wider tourism market have triggered a significant offer of hostel accommodation facilities, specially profiled and targeted at younger groups. The special role of hostels within the overall demand and recognition of the broader market is also necessary to improve the classification of their own level of quality, market power and clear attitude of the regulated offer, all types of accommodation facilities, specific and unique tourism market.

Significant upgrading of the role of the hostel within the total supply of accommodation capacities in the domestic tourism market is reflected in the creation of necessary conditions for quality standardization and hostel categorization, which is the best way to define the city and market position of the hostel. The strong interdependence with other forms of accommodation as well as the need to define the level and quality of sorted standards, defines the uniqueness of the hostel type and quality along with improving the strength of the local accommodation facilities.
\end{abstract}

\section{Keywords:}

classification, quality, market competitiveness, interdependence, improvement.

\section{INTRODUCTION}

Youth tourism is a special form of universal tourism activities that require the defined and applicable requirements and market implementation. It is characterized by creativity, need for socializing and communication research character of young service users with the full responsibility of key stakeholders, especially in the processes and stages of tourism organization, execution and monitoring (Jovanović, 2013, pp. 172-173). Balanced and institutionally regulated relationship of various accommodation facilities is an important precondition for stable functioning of the tourism market based on the clear standards and categorization of all forms of hostel accommodation and other facilities for young people. Institutional regulation of relationships between various accommodation conditions is the stable and organized business and realization of anticipated economic effects. Domestic accommodation facilities are 
categorized by defined laws and regulations. These include hotels, motels, tourist resorts, camps, pensions and the annex, immediately categorized by the relevant ministry, as well as houses, apartments, rooms and rural tourist households, which in practice categorizes the designated authority of the local government.

Recognizing the importance of the hostel, the need for institutional and qualitative regulation of this type of service and the possibility of rapid development, has led to the necessity of a unified classification in relation to the overall quality level of accommodation and tourism offers. Clearly defined market positioning within the single domestic market and accommodation service, will mean the clear institutional and economic support to the development of hostels and regulations of relations of the key types of accomodation.

\section{RESULTS AND DISCUSSION}

The prinicpal focus of this research is youth tourism and comparative definition of hostel facilities and activities in relation to the total capacity of categorized domestic housing and real impact on the single market offers of accommodation capacities. The uniqueness and synergistic cohesion of accommodation facilities in the single tourism market is a clear precondition for improving the overall functioning of the same. Hostel categorisation is performed according to the level of quality standards contribution to the qualitative and quantitative improvement of the tourism market forces, the development of underdeveloped tourism locations and destinations, raising the standards of quality accommodation capacities, harmonization of the pricing policy on the single market and improving numerous other socio-economic and social characteristics.

Positioned power of hostel: By longtime representation on the wider tourism markets, hostels provided a significant role in the market organized hotel accommodation, achieving significant economic and other business effects. The character of the hostel is measured with a special role in improving the social relationships among young people worldwide, as well as an additional mode of education, or entertainment and achievement of significant financial effects

According to the available data for the year 1970, the Youth Hostel Association of Serbia (FHSS), which is a member of the International Youth Hostel Federation, the international association "Hostelling International Association" (HI), included about 3,500 hostels in around 80 countries. Voluntary membership of 3,694 hostels was recorded in 2011, or 4009 hostels in 71 countri- es in 2014, with $1,628,907$ beds and 35,806,968 overnight stays. These data continuously vary recording the change and significant economic expansion with the annual revenue of about \$ 15 billion. Germany, with around 252 registered hostels as well as England, France, the USA and Australia are the countries with the most important and most professionally organized hostel accommodation facilities and capacity, quality, safety and revenue in the industry. ${ }^{1}$ According to the previously conducted statistics, youth traveling is considered to make up about $1 / 5$ of total tourist trips, according to the UNWTO, and around $30 \%$ of travel are realized by young people, which is why oscillations of youth work to the hotel, or the socalled hostel are not surprising.

Characteristic demarcation: Developed long and typical business practice in the hostel industry in the domestic and broader international markets, particularly the experience of the international hostel organization " $\mathrm{Ho}$ stelling International" contributes to the identification of a set of positive values and characteristics that have made this lodging achieve the sustained market positioning. "HI" over the rules of conduct and quality standards contributes to establishing minimum quality standards necessary for the achievement of applicable roles in the wider tourism market.

The fulfillment of minimum conditions of international " $\mathrm{HI}$ " sign of quality, as well as harmonization and evaluation in practice, have established evaluator quality standards, following the general conditions and specific binding criteria in practice, such as hospitality, cleanliness, security, privacy and comfort. Hostelling Intentaional classification identifies three categories of classified standards of quality: The lower grade (exceptionally for a lower level in simple hostel in the secondary and remote locations); Standard level (a common and expected quality of the hostel which is true for most objects); Higher degree (Hostels beloning to this category are positioned at the most important locations, destinations and routes without the exception to the comprehensive organized promotion of the largest number and selection of the best service capacity).

In domestic terms of accommodation and tourism practice, the concept, types and functions of the hostel are not conceptually, clearly defined and determined, which is why the existing institutional framework is often not sufficient to comply with the minimum standard for successful implementation and development of this type of characteristic accommodation facilities on the open market. Leisure facilities are designed under-prescribed standards and common behavior often cannot be characterized as clearly and firmly established

1 http://serbia-hostels.org 
rules of behavior in the workplace or prescribed standard, so it can sometimes cause undesirable conduct and lack of understanding of the key actors in this kind of accommodation services. $^{2}$

The hostel industry in Serbia: This hostel industry (hosteling) as a characteristic of the target profiled lodging, occupied and / or can occupy a significant segment of the tourism market order accommodation facilities, site development schedule and clearly defined approaches towards the target groups. According to the current schedule and location capabilities, of simply launch and significant development in relation to the hotel facilities of lower categories, hostels wish their development capacities to be suspended "a competitive" but conceptually important synergic-storage capacity, which contributes to the overall improvement, market supply and forces the tourism market organized accommodation, as well as the provision of related software and special services to guests.

On the basis of comprehensive records of the Youth Hostel Association and Serbian Business Association of Hotel and Catering Industry HORES in 2013, Serbia had about 100 registered hostels, and about 87 in Belgrade. Major expansion started around 2004, and especially after 2009, when about 10 to 20 hostels were opened per year, but is constantly recording a significant number of closures due to irregular registration which is hard to determine (Kosar \& Ristovski, 2013, p. 304). According to official site of Youth Hostels Association of Serbia in 2010, a total of about 52 hostels was recorded in Serbia, 36 of which in Belgrade. It should be noted that in the early, middle and late decades of the last century, youth tourism devoted significant attention to organization of children and youth major resorts that can now be seen in the significant not organized and special conditions.

In the Republic of Serbia, there is unofficially about 175 hostels registered, of which the largest part is in Belgrade. This arrangement provides special opportunities and development possibilities in the interior, especially where a schedule of hotel accommodation is inadequate character of the site, the possibilities of developing a

2 In the elaboration of research themes of this paper, the author in accordance with the existing system of domestic methodology bylaws regarding categorizing accommodation, simulate and made a complete practical normative elaboration in order to test and prove the possibilities of creating the necessary and applicable normative regulations for domestic categorization of the hostel including: "ordinance on standards for categorization of hospitality facilities for hostel type accommodation; ordinance on conditions and manner of conducting commercial activities and provide catering services, the classification of establishments and the minimum technical and sanitaryhygienic conditions for the planning and catering facilities for hostel type accommodation; and standard sorting hostel in the category." tourism destination or options for the construction and renovation of existing facilities. It is estimated that the average number of beds per local facilities is about 21 , but it should be noted that there is a significant number of bunk beds, which significantly increases the estimate of the total number of beds in relation to the estimated total number of beds. It can be concluded that local hostel accommodation has a total of about 3,675 beds, of which 1,953 in Belgrade, which accounts for about 53\% of the total capacity of beds in hostels.

\begin{tabular}{|c|c|c|c|c|}
\hline Location: & $\begin{array}{l}\text { Beds / } \\
\text { rooms }\end{array}$ & $\begin{array}{l}\text { Members } \\
\text { of objects }\end{array}$ & $\begin{array}{c}\text { Numbers of } \\
\text { beds }\end{array}$ & $\%$ \\
\hline 1. Belgrade & 21 & 93 & 1.953 & $53 \%$ \\
\hline 2. Serbia & 21 & 82 & 1.722 & $47 \%$ \\
\hline \multicolumn{2}{|l|}{ Total: } & 175 & 3.675 & $100 \%$ \\
\hline
\end{tabular}

In relation to the total registered (categorized) hotel accommodation, hostels record around $12.5 \%$, which is unsatisfactory participation and indicates and confirms the unique problem of total occupancy of accommodation capacities in the domestic tourism market. The problem of insufficient availability of accommodation capacities in local industries also expressed oscillating trends, and thus deepens the problem of occupancy of comprehensive national capacity to accommodate guests.

Domestic hostel accommodation characterized the work of a range of hostels without the stable and longterm business concept and therefore, classification of any kind of categorization. Promotion is an individual activity of individual hostel in accordance with the personal assessment of their own organization, quality, technical and personnel capabilities and market-presented policy operations, sales, price and others. Notwithstanding the uncertain standards and disaggregated categorization, specifics inherent to each individual hostel determine the position of each hostel and hostelling activities in the total domestic demand for the subject and the capacity to accommodate guests. Business in the area of organized institutional type of hotel and similar accommodation services in relation to the creative accommodation homemade hostels determines the special role and importance, including the balanced linking of the overall resource type and accommodation capacity of the domestic tourism market. This creates a compact and meaningful market cohesion of local accommodation capacities of a single tourism market. This role of the hostel can be very successful but often place special refractive market problems and anomalies within the organization offers complete single market accommodation. 
Hostel and other types of domestic accommodation: Article 68 of the Law on Tourism of Serbia shall determine the manner of classifying and categorizing catering facilities for accommodation. Hotels of all kinds, motels, tourist resorts, camps, inns, and the annex are the responsibility of the Ministry of Trade, Tourism and Telecommunications of the Republic of Serbia (MTTT, 2015), ${ }^{3}$ while the hospitality facilities for homemade accommodation (house, apartment, room, and rural tourist house hold), sorted into categories in accordance with the standards established and implemented by the competent authorities of local governments. As regards hostels as a kind of organized accommodation, there are no comprehensive, special and uniquely defined and laid down minimum conditions and manner of performing commercial activities, catering services, the classification of catering facilities as well as minimum technical and sanitary and hygienic conditions for the planning and catering facilities of this kind. In this way, the home hostels are not enough, or not desired and possible way, achieve significant participation and influence on the domestic market accommodation facilities in the single tourism market. The existing binding and referral minimum rules for the organization and operation of the hostel are currently contained in the work of the national legislation and subordinate legislation governing the operation of tourism and commercial activities, as well as the overall economic activity and the minimum specialist regulations that directly regulate commerce facilities for storing, preparing and serving food and beverages and other ancillary and supplementary activities performed in hostels. The average status of local facilities and the capacity to accommodate guests, which are the methods of categorizing the jurisdiction MTTT, compared to the number of buildings, units and beds, stream $(2014,2015,2016)$ are as follows: ${ }^{4}$

\begin{tabular}{lccc}
\hline & $\begin{array}{c}\text { April } \\
2014\end{array}$ & $\begin{array}{c}\text { August } \\
2015\end{array}$ & $\begin{array}{c}\text { May } \\
2016\end{array}$ \\
\hline $\begin{array}{l}\text { 1. Registered graded facili- } \\
\text { ties for accommodation: }\end{array}$ & 350 & 352 & 362 \\
\hline $\begin{array}{l}\text { 2. Registered graded units: } \\
\text { 3. Registered categorized } \\
\text { beds: }\end{array}$ & 17.062 & 17.897 & 18.069 \\
\hline
\end{tabular}

3 Art. 27. "Regulations on standards for categorization of hospitality facilities for accommodation" determining categorization other facilities by type: home, apartrmani, rooms, rural tourism households and hostels are the responsibility of local government (Official Gazette of RS, 41/2010, 103/2010, 99/2012).

4 Determining of categorization of other facilities based on their type: houses, apartments, rooms, rural tourism households, and hostels, is the responsibility of the local government.
Regarding the total number of domestic categorized properties, hotels have the largest share in terms of the number of objects and the number of units and beds. In the period from 2010 to 2014, the number of types of hotel properties (including garni and apart hotels) rose from 251 to 328 , i.e. $30.7 \%$. The increase was also accompanied by units which in 2010 was 15,357 and in 2014 16,961 , representing an increase of $10.4 \%$, while the number of beds increased in this period from 24,186 to 28,501 , or by $17.8 \%$ (MTTT, 2015). There is a necessity of further institutional upgrading and linking of analytical monitoring and processing activities of groups and categorized types of accommodation in order to touch a segment jurisdiction MTTT and local self-synchronize the introduction of hostel categorization. The role and significance of hostels can be connecting the accommodation market segment that establishes a special effect, the wider business correlation and conditional, mutual relationship with hotel accommodation $1^{\star}, 2^{*}$ or even $3^{\star}$ as well as the work of accommodation in the local arts and crafts. Currently, the interrelation is negative competitive in this segment of work in domestic market accommodation

The attitude of hostels and other accommodation facilities in the domestic market: Hostels occupy the market position of facilities for housing, which in many characteristics and aspects of work indicates significant development and market opportunities. Improving the operation and development of hostel accommodation in a certain way can be considered competitive compared to other types of graded facilities and the capacity to accommodate types of hotels, motels and inns and this variety of classified medium and lower quality standards. When it comes to hostels in better locations and/ or higher quality, with an emphasis on own target groups of young people, recognized the market competitiveness and strength compared to similar objects in other types of organized accommodation. Hostels in relation to other facilities to accommodate up to a maximum of $3^{*}$ can be very competitive and in a good part uncoordinated.

Hostels as unclassified objects in spite of all the differences in relation to other types of accommodation often occupy a position of unfair competitor. The current position of hostels within the local offer of accommodation facilities is not adequate by the abilities and needs. In addition to his work next to generated effects and good practice examples, hostels recognized many shortcomings that need to be rehabilitated and improved. Stronger institutionalization and introduction of categorization create the conditions for stronger conceptual demarcation, establishing clear business conditions as well as the full force of promotional and presentational 
role that fully promote this type of accommodation but also the overall governing nomenclature and accommodation, classified by type, quality and market differentiation, sales and price policies and others. By analyzing the structure of the target groups and guests in the domestic tourism market, it can be concluded that hostels in many comparative parameters conditionally monitor the operations of hotels and other lodgings based on the trends and occupancy achieved and at price levels, the results achieved, guest satisfaction and others.

Hostels in the business market generate significant direct and interactive impact compared to similar types of hotel and accommodation facilities categorized objects $1^{*}$ and $2{ }^{*}$ in special cases and to facilities for the accommodation of other types and up to $3{ }^{\star}$ Stepan classified categorization. Types of facilities and capacity of hotels and similar types of accommodation which are categorized directly, largely exposed or could be exposed to conditional and reciprocal aspects of the mutual work of the hostel are:

\begin{tabular}{|c|c|c|c|c|}
\hline Type of objects & $\begin{array}{l}\text { Number } \\
\text { of objects }\end{array}$ & $\begin{array}{c}\text { Number } \\
\text { of apart- } \\
\text { ments }\end{array}$ & $\begin{array}{l}\text { Number } \\
\text { of rooms }\end{array}$ & $\begin{array}{c}\text { Number } \\
\text { of beds }\end{array}$ \\
\hline 1. Garni hotel * & 4 & 0 & 14 & 26 \\
\hline 2. Garni hotel ${ }^{*}$ & 30 & 21 & 486 & 830 \\
\hline 3. Pansioni ${ }^{\star}$ do ${ }^{\star * *}$ & 3 & 19 & 59 & 122 \\
\hline 4. Hotel ${ }^{\star}$ & 14 & 42 & 1.263 & 2.250 \\
\hline 5. Hotel $* *$ & 56 & 125 & 2.139 & 4.047 \\
\hline Total: & 107 & 207 & 3.961 & 7.275 \\
\hline 6. Garni hotel ${ }^{* * *}$ & 38 & 101 & 800 & 1.497 \\
\hline 7. Hotel $* * *$ & 78 & 393 & 3.975 & 7.298 \\
\hline Total: & 116 & 207 & 4.775 & 8.795 \\
\hline
\end{tabular}

Characteristics and specific aspects of domestic hostel accommodation: As regards the work of local hostels, we can say that that it is primarily the product of individualy organized hostels, which in addition to its own initiative, the maximum level of creativity, with personal investment and organizational capacities and individual entrepreneurial spirit, realizing the effects of the business. Personal initiative is among the most important elements for quality and successful hostel business. Opposite the successful and in all quality hostel activities, we can see a series of burdensome and desorganisational characteristics that are considered essential and professional guidance for successful work. This approach is not sufficient for significant development of domestic hosteling. Special observed deficiencies are common and under-designed promotional appearance on the market that support individual interests and enable the organization's stronger representation and recognition and protection of interest and market positioning of associated hostels.

In addition to the previously indicated aspects of domestic hostel practices, other characteristics can be observed:

- Insufficient utilization of resources for the work on the hostel „undiscovered“ locations and destinations;

- Insufficient care and support in the hostel business as separate and specific types of accommodation;

- Lack of clear, unified and development of standards and rules of categorization;

- Insufficient training of key actors and direct perpetrators of the hostel operations;

- General institutional marginalization, particularly in public spaces and unify business rules;

- Non-existent system of monitoring, evaluation and assessment of individual hostels;

- High degree of improvisation in the work without supporting the operation and development of the hostel;

- Low level of professional monitoring, support, recording and analytical-statistical interpretation;

- Other features which are indicated in the paper or seen in the work of the hostel in the domestic market.

Identified problems of domestic hostel industry are lack of unique technical and technological normative base which is necessary to define business methods and strategies used in the hostel industry, as follows:

a) Previous aspects of interior decorating conceptual demarcation for improving the organization and functioning of the hostel to the adoption of necessary rules of conduct in the hostel business (Petković \& Mitrović, 2013, p. 429); 
b) Establishment of a system of hostel categorization in accordance with the quality standards and goals for improving the market position of hostels and other domestic accommodation capacities;

c) Institutionalization of rules, conditions and standards of the local hostel activities to include in a regular resource of categorized accommodation facilities under the jurisdiction of MTTT a process of categorization entrusted to the jurisdiction of local governments (Kosar, 2011, p. 97);

d) Creating the conditions for institutional strengthening of care for young people through the development of domestic tourism hostel activities, specifically governed by compliance with the $(H I){ }^{5}$

It is necessary to implement a number of other activities to the beneficial hostel domestic operations among which are the following:

a) Adoption of necessary secondary legislation by MTTT the Government of the Republic of Serbia (Kosar \& Ristovski, 2013, p. 304); Ordinance on standards for categorization of hospitality facilities for hostel type of accommodation; Ordinance on conditions and manner of conducting commercial activities and the provision of catering services, classification of establishments and the minimum technical and sanitary-hygienic conditions for the planning and catering facilities for hostel accommodation; Standard hostel sorting into categories;

b) Introduction of obligatory registration of statistical, analytical and other necessary monitoring of hostel accommodation with the elaboration and implementation of the system of education, support and subsidies for the development and improvement of the hostel (Kosar \& Ristovski, 2013 p. 307);

c) Completion of the complex realization of tourism register aimed at improving the work of the tourism industry;

d) Support the advancement of the association HORES, the Youth Hostel Association of Serbia, and other professional associations, improvement of cooperation with "Hostelling International Association" and others;

e) Networking unified communications and operating system and support the definition of the

5 Institutional regulation of cooperation and relations with Business association of hotel and restaurant industry - Serbia role and place of satellite accounts in the improvement of market power of local capacities and domestic tourism development;

f) Other progressive and development activities.

\section{CONCLUSION}

Hostels require a clear business target model and cannot be developed without a stronger institutional and normative framework and working conditions. Significant upgrading of the role of hostels within the total offer of accommodation facilities in the tourism market is identified with the aim to create the conditions for hostel standardization and quality categorization, which best defines the city and market position of the hostel and overall youth tourism.

Hostels have defined a clear target business model and certainly cannot be developed without a stronger institutional and normative framework and working conditions. Significant upgrading of the role of the hostel within the total offer of accommodation facilities in the tourism market identified in the need to create conditions for standardization and quality categorization of the hostel, which in the best way defines the city and market position of the hostel and total tourism for young users.

Development hostel activities fully support further investment and development projects in the domestic tourism market, which can be considered innovative in terms of flexible needs and desires of youth tourism. Proper assessment, implementation and supervision of conditions for organised tourism promotion for young people and taking responsibility for the establishment of institutionally defined and minimum work requirements of the local hostels, primarily based on the minimum established rules, conditions and quality standards, ensuring full general health, safety and security, good communication and hospitality to young tourists.

\section{REFERENCES}

Jovanović, V. (2013). Tematski turizam. Beograd: Univerzitet Singidunum.

Kosar, Lj. (2013). Alternativni standardi kategorizacije u hotelijerstvu. Hotel-link, 11(21/22), 1.

Kosar, N., \& Ristovski, M. (2013). Hosteli kao nova razvojna šansa smeštajne ponude Srbije. Hotellink, 11(21/22), 1.

Ministry of Trade, Tourism and Telecommunications. (2015). Zakon o turizmu. Retrieved August 12, 2016 from http://mtt.gov.rs/download/1(2)/ZAKON\%20 O\%20TURIZMU.pdf 
Petković, G., \& Mitrović, M. (2013). Razvoj omladinskog turizma Srbije. Uticaj globalnih turističkih tokova na kvalitet hotelskog poslovanja/ IX Medunarodni naučno stručni-simpozijum Hotelska kuća 2013, Zlatibor, Novembar 2013. (str. 427-437).

Službeni glasnik Republike Srbije. (2012). Prvilnik o standardima za kategorizaciju hotelskih objekata za smeštaj. Službeni glasnik RS, br. 41/2010, 103/2010 i 99/2012.

UNWTO. (2015). Annual Report 2015. Retrieved August 12, 2016 from http://cf.cdn.unwto.org/sites/all/files/ pdf/annual_report_2015_lr.pdf
Vukotić, J. (2013). Na korak od evropske hotelske kategorizacije. Hotel Life: Magazin of Hospitality Management, 2(2013), 24-27.

World Economic Forum. (2015). Annual Report 2014-2015. Retrieved August 12, 2016 from http://www3.weforum.org/docs/WEF_Annual_Report_2014_15.pdf 